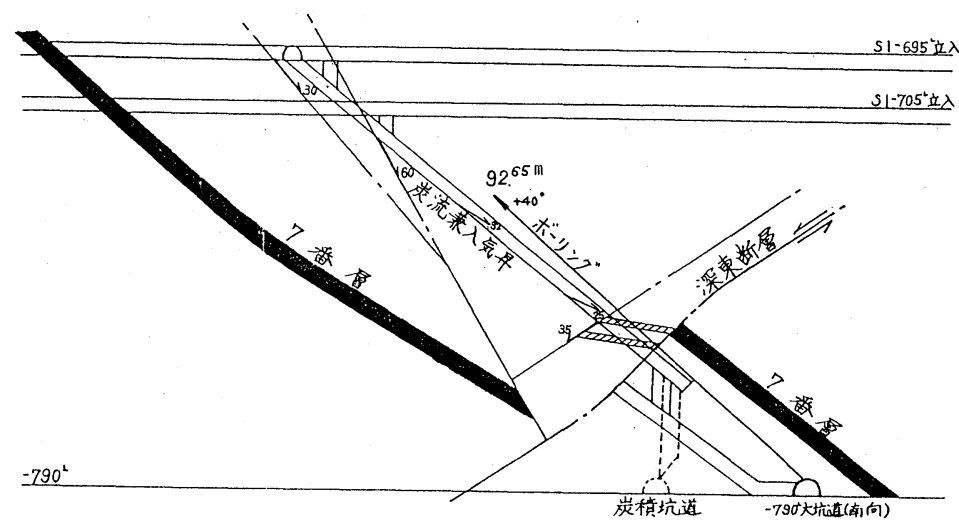

第3 図 炭流兼入気昇地質断面図

回収については, インナーチューブのナット調整でピストン外 径が拡大されており, 回収時に水の抵抗が大きいため, 逆にポン プで水を抜き出しながら回収作業を行なつた。

工事結果は，掘削深度約 $92 \mathrm{~m}$ に対して，方当たり約 $9.3 \mathrm{~m}$ の高 錐進能率を得, 孔曲りもほとんど生じなかつた。

\section{4. ストラタパックスビットの使用}

ワイヤラインボーリングで, ダイヤモンドビットが幅広く使用 されているが, 最近ノンュアボーリングで人工ダイヤで加工した ストラタパックスビットを採用し，錐進能率が飛躍的に向上して いる。

ストラタパックスビットは, ビットのボディに冈先となるスト ラタパックスドリル素材を植付けたものである。このドリル素材 は，超硬合金（タングステンカーバイト・コバルト）の基体上に， 粉末ないし細粒状の人工ダイヤモンドを焼結したもので, 超硬合 金の耐衝撃性とダイヤモンドの耐摩耗性とを併せ持つている。た だ弾性的な脆さがあり, 砂岩層等の硬岩には不適当である。メタ ルビットが圧削, ダイヤモンドビットが研削によつて切削するの に対して,このストラタパックスビットは剪断により切削するの で, 適応した岩種では高能率の掘削が期待できる。

当鉱では, 59 年度からストラタパックスビットを採用し, 錐進 能率で, 従来ダイヤモンドビットでの平均能率 $5.7 \mathrm{~m} /$ 万に対し

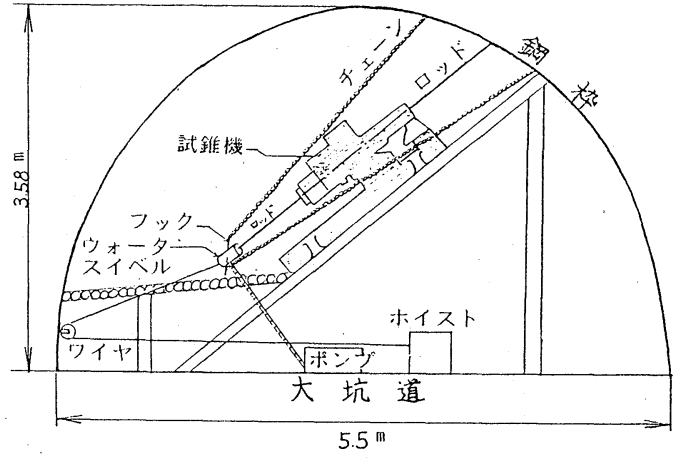

第4 図 作業箇所概念図

て, $9.2 \mathrm{~m} /$ 方の好成績を得ている。

なお, 現在はストラタパックスを6 個埋込んだビット を使用しているが，この素材が高価であることから，ビットの形 状と併せて，その個数減を検討したい。

\section{5. むすび}

現在, 中・長期探査で使用している掘削深度 $500 \mathrm{~m}$ を越える大 型試錐とは別に, 部内の坑道展開に先がけて，これまでのスライ ム探査に代わり，区域的に精度の高い探査が手軽にできる小型ワ イヤライン試錐機の開発が要望されていた。

57 年度以降, エア駆動の小型ワイヤライン試錐機 (FS-20 P) を開発導入し, 現場での適用試験と改善を繰返してきた。この結 果，区域探査に有効な試錐機であることが実証された。

なお，本機は小型・軽量で錐進能率の優れた機種ではあるが, スピンドル内径が $60 \mathrm{~mm}$ であるため, 岩石破碎部や炭層のコア採 取率がまだ低く，またケーシングの挿入作業に難点があるなどの 問題が残つている。

今後, ドリルニニットのーッド部に改良を加え, スピンドル内 径を $80 \mathrm{~mm}$ に拡大すること，またビットの形状を改良するなどし て，より高能率なボーリング技術の確立を目ざしたい。

最後に, 本工事の推進に当たつて, 石炭技術研究所のご理解, ご援助を賜り, また本機種の開発に関して鉱研試錐工業 (株)の協 力を得た。ここに関係各位に対し厚く感謝の意を表する。

\title{
〔一般講演〕
}

\section{（6）太平洋炭鉱における袖巻充塡用木積の強度試験について}

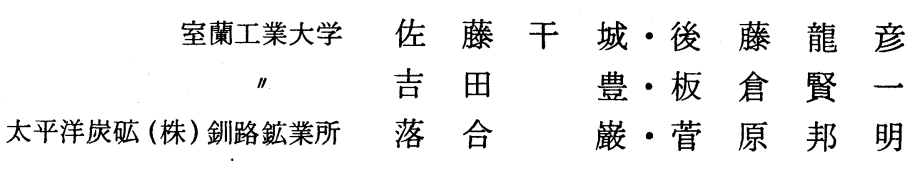

\section{1. 緒言}

太平洋炭矿釧路鉱業所では昭和 51 年以来, 実收率向上, 深部化 抑制を目標に, これらを達成するため種々の新技術開発に取り組 んできている。そのうち現在実技的に完成しているものとしては 風坑の省坑道化を目的とした採掘跡ライナ坑道, 炭層の完全採掘 ならびに深部化抑制のための薄層採炭も実施され，一応の成果を 挙げている。しかしながらこのような新技術開発にもかかわらず, 採掘跡通気遮断のため依然として隣接坑道間には炭柱を残さなけ ればならず, これが実収率アップの目的に対し大きな支障となつ ていた。そこでこの問題を解決するため, いわゆる無炭柱採炭を
目ざし, しかも省坑道による坑道維持の工数減も含め新しい採炭 坑道展開について当鉱の条件を考慮しながら種々の検討が試み られた。その結果袖巻充填により坑道を維持し, 切羽採炭時に重 複使用する方式が採用され，これに基づき充媜材，木材の選定， 輸送方法等がテストされ, 昭和 58 年 7 月から中央西 7 片上添 2 号 切羽で試験的に実施された。しかしながら本方式に対する基本的 考えには問題はないが, 袖巻進行速度が $3.8 \mathrm{~m} /$ 日と低く, 切羽 進行速度に追従できず, 改善の必要にせまられた。その後 2,3 の現場計測等を試み, 袖巻構築作業量の軽減に主眼を置き設計に 改良を重ね現在の方式に至つている。

このように坑道の袖巻充媜は実収率アップのため現時点で最良 
の方法と考えられ，諸外国はもちろんのことわが国でも多数の炭 鉱で試みられており，その方法も多種多様である。一般に袖巻構 造としては木材と各種充媜物との組み合わせから構成されるが, その構造物自身の挙動に関しては不明瞭な部分が多く, 経験的で ある。

ここでは現在当鉱で主に使用されている袖巻構造物を対象に， その力学的挙動を明らかにし, しかもそのデータを坑道維持管理 に役立てる目的で, 実規模載荷実験を行なつた。以下にその結果 ならびに現在までに本構造で維持された坑道の実績等について報 告したい。

\section{2. 袖巻坑道の構造と構築状況}

現在当鉱で採用されている袖巻坑道の構造は採炭切羽の炭丈に より, 大きく中高層用, 中層用, 薄層用の 3 種に分類される。第 1 図はこれらの状況ならびに寸法等を示したものである。中高層
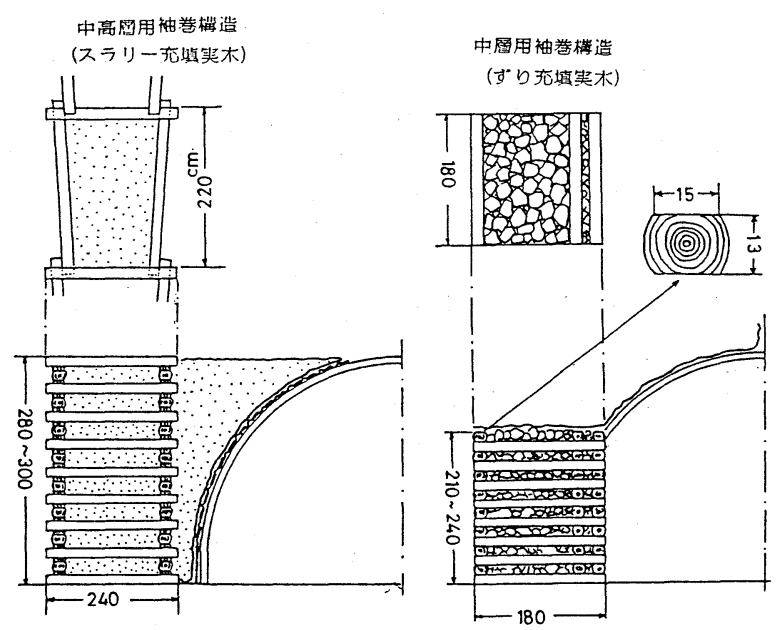

第1図袖巻充媜坑道の構造

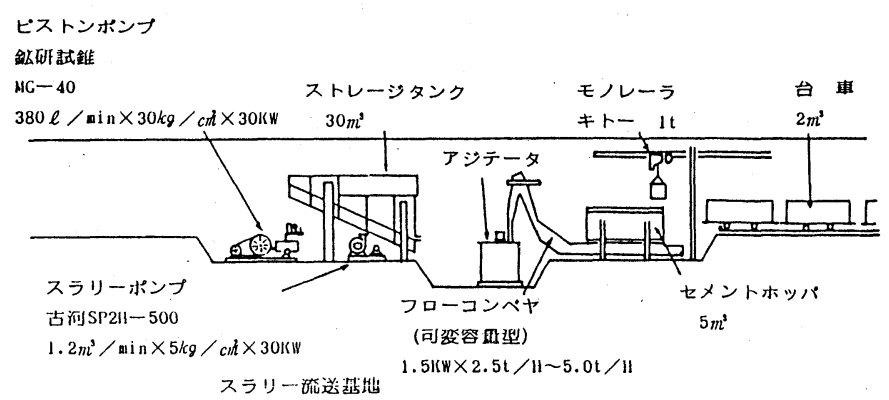

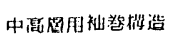

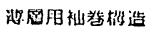
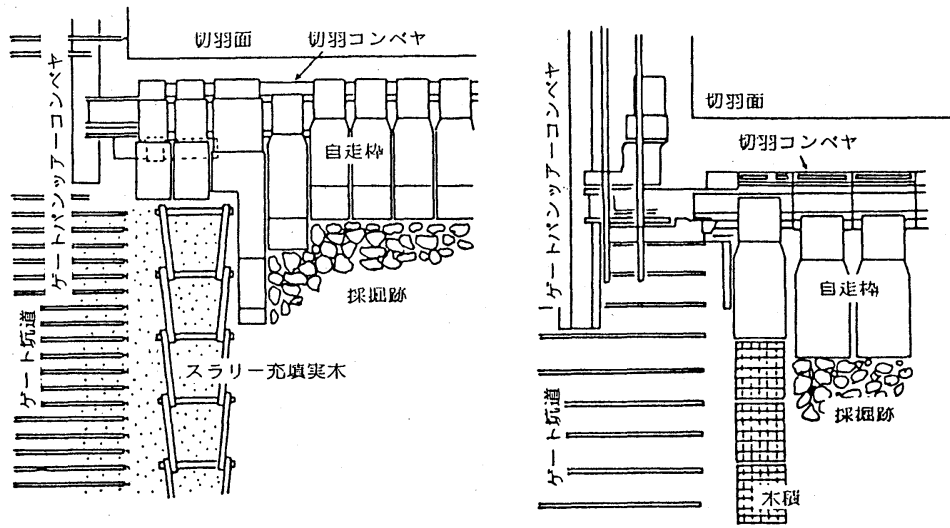

第2図 スラリー流送充填基地と切羽での構築状況

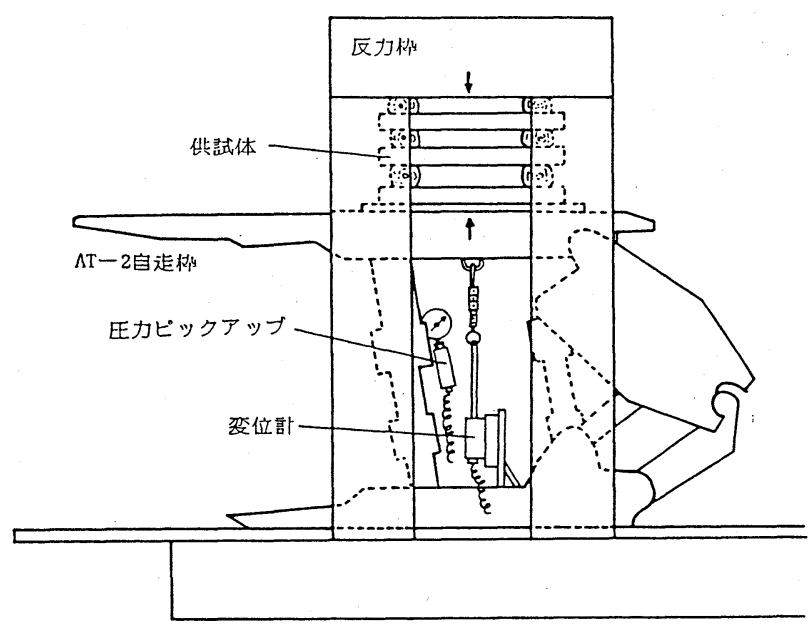

\section{第3図 載荷試験装置}

用袖巻構造は木材とスラリー充填物か らなり，木材をいげたに組みその中に 選炭廃水スラッシシにセメントを添加し たスラリー状のものをいげた内部に貼 り付けた袋内に流し込んだものである。 また中層用袖巻構造は前者とほぼ同様 な構造であるが，スラリーの代りに岩 石ずりを用い充填した。一方薄層用の ものは図からも明らかなように木材を 交互に密に組み込んだものであり，あ たかも 1 個の角材で構成されたような 状態を呈している。ここのように数種の 袖巻構造があるが, ここでは都合上木 材のみをいげたに組んだものを空木,

スラリー充填をほどこしたものをスラリー充填実木, 岩石ずりを充填したものをずり充媜実木，薄層用の ものを木積と呼ぶことにする。なおここで使用した 木材はすべてから松である。

採炭切羽の炭丈に応じ袖巻構造は異なるが, 切羽 での構築はほぼ同様であり,ここではスラリー充媜 実木および木積を例としその構筑状況を説明したい。 第 2 図はスラリー流送基地ならびにこれらの構築状 況を示したものであり，スラリー充填実木の場合自 走枠後方で空木が組まれ，その中に基地プラントか らスラリー流送管を通し充填される。

このように自走枠後方で構築された袖巻構造物は 切羽の前進に伴い天盤から荷重を受けるが，その際 の載荷履歷としてはまず採掘跡内の地圧を受ける。 さらに重複使用を目的としているため，隣接切羽採 炭時にはその先行圧の影響を受けることになり，合 計 2 度の地圧変化に耐えなければならない。このよ うな外部からの地圧変化に対し, 袖巻構造物は力学 的にどのような応答をするか調べるため実規模で載 荷実験を行なつた。

\section{3. 載 荷 実 験}

載荷試験装置としては当鉱所有の自走枠試験機を 応用することにした。すなわち第 3 図に示すように 自走枠天盤カッペ上に袖巻構造物をセットし, 自走 枠の水圧ラムを上昇させることにより，反力枠と天 

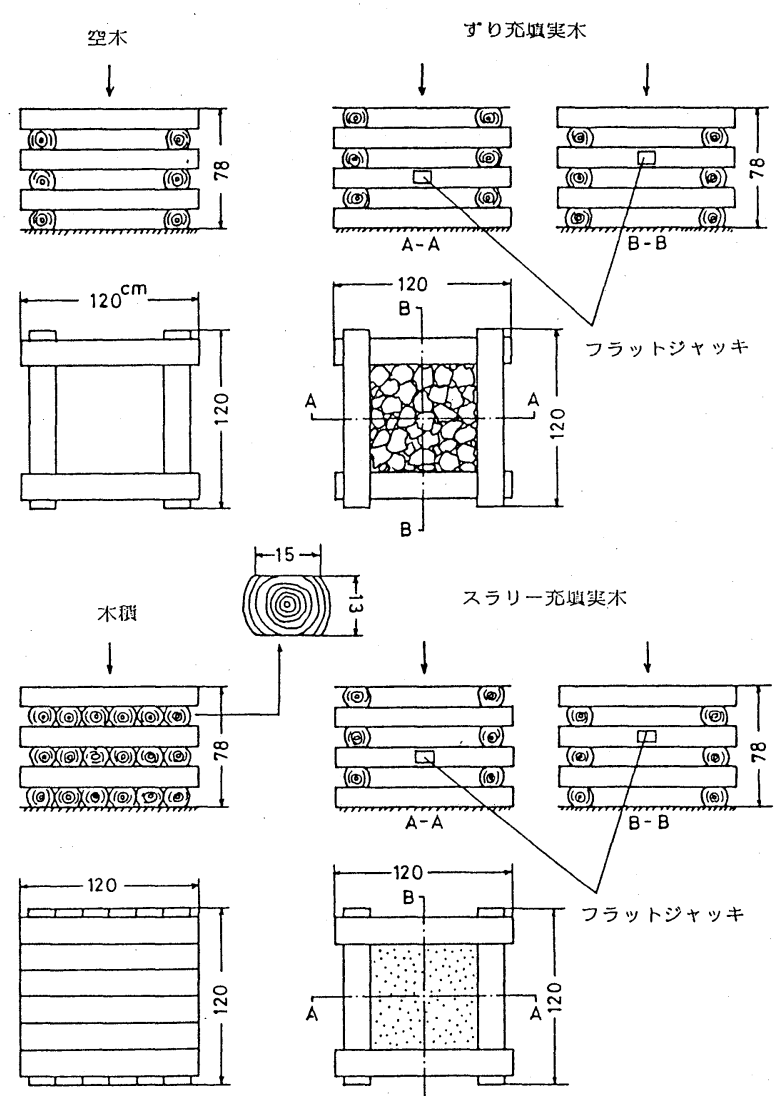

\section{$($ ((은) $)\left(\begin{array}{l}15-1 \\ \frac{1}{\omega} \\ 1\end{array}\right.$}

スラリーテ范趾笑木

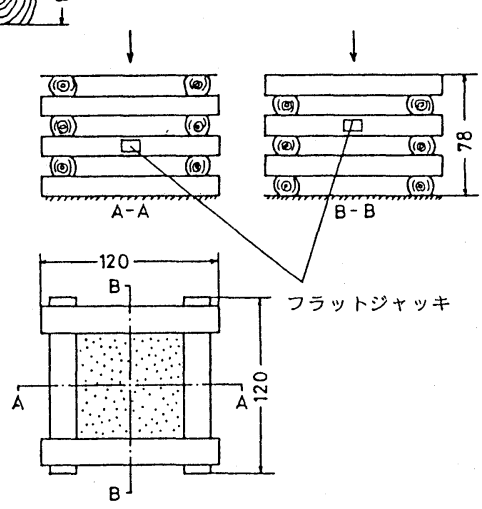

第 4 図 試験対象袖巻構造物

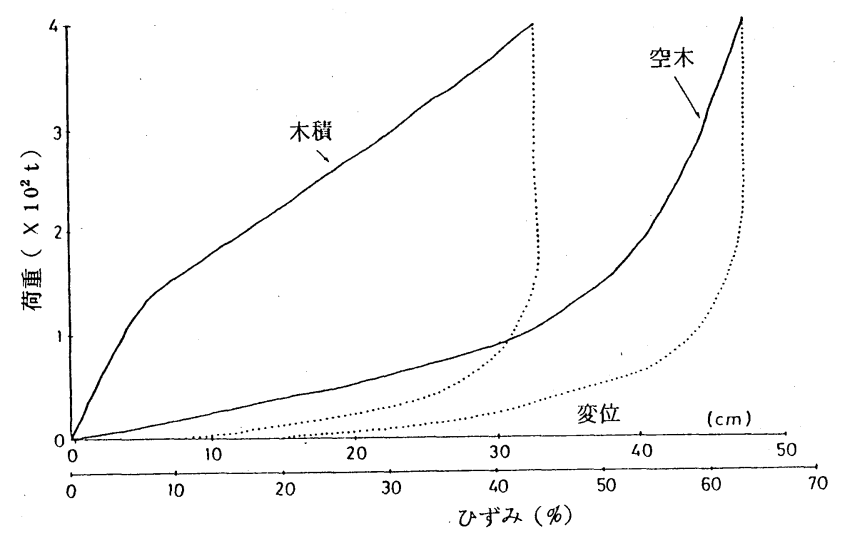

第5図 荷重～変位曲線（空木，木積）

盤カッペ間の袖巻構造物は圧縮荷重を受けることになる。そのた め本装置の容量は自走枠容量と等しく400tであるが, 荷重計測 は水圧を圧力ピックアップでモニタし，これを荷重に換算した。 一方袖巻構造物は压縮荷重を受け変形するわけであるが, その変 形量は自走枠内に設置された容量 $50 \mathrm{~cm}$ のコンベックスタイプ変 位計で測定した。な掎重および変位はアンブを通しXーYレコ 一ダに荷重〜変位曲線の型で出力される。ここでの試験対象袖巻 構造物は 4 種類で, それぞれ空木, スラリー充填実木, ずり充媜 実木, 木積である。第 4 図はこれらの寸法等を示したものである が, 装置の都合上構造物全体の寸法は実際のものより小さいが, 使用木材, 充填物等はまつたく同様であり, ほぼ実規模試験と考 えてさしつかえないであろう。またスラリーおよびずり充填実木 の 2 つに関しては, 充填物および木材の載荷により生じる横方向 変位量の相異が反力として発生するわけであるが，これをモ二タ

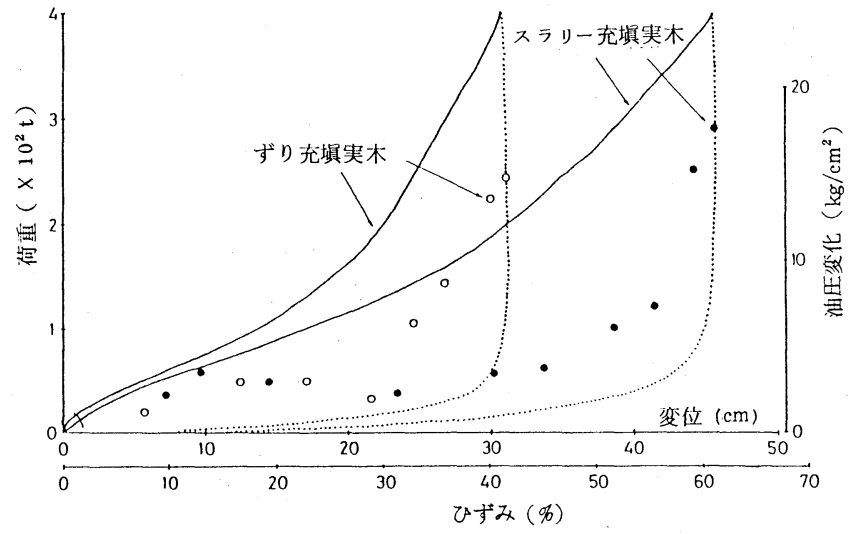

第6図 荷重〜変位〜油圧変化曲線（ずり充填実木， スラリー充填実木 )

するため, 図に示す位置にフラットジャッキを設置し，その油圧 変化も同時に計測した。

第 5 図は実験の結果得られた空木および木積の荷重〜変位曲線 であり, 縦軸は荷重, 横軸は変位およびひずみである。なお荷重 は本装置の最大容量まで負荷した。空木の挙動をみると, 曲線は 変位 $30 \mathrm{~cm}$ から $40 \mathrm{~cm}$ を境としほぼ 2 直線で近似でき, その傾き がこの袖巻構造物の剛性となる。実験時の観察によると, 最初の 直線部分は各上下間のはり空間を減少させるように変形が生じ, そのため変形量は大きい。その後各はりが密着し空間の存在がほ とんど認められなくなると, 第 2 直線部分のように変形が急激に 小さくなり, 両直線の変曲点付近の变位量は試験前の各上下間の はり空間高さの総和にほぼ一致している。なお実験後の観察によ ると, 木材の円形断面は放射状, 支点間はりには長さ方向に平行 な亀裂の卓越が認められた。

.一方木積の変形挙動に関してはこの場合もほぼ 2 本の直線で近 似され, これらは各木材の局部的破壊前と後に対応しており，も ちろん前者の方が後者に比べ変形量は小さい。また木材の円形断 面にはこの場合も放射状亀裂が観察された。

第6図はそれぞれスラリーおよびずり充填実木の結果であり， 図の説明は前図と同様であるが, 変形に伴うフラットジャッキの 油圧変化も示してある。なお油圧変化はそれぞれ 2 枚のフラット ジャッキの平均值を採用した。両荷重〜変位曲線とも 2 直線で近 似され，その傾きはずり充媜実木の方が大きい。これは充填物そ のものの変形性に大きく依存し，この場合ずりの方がスラリーよ りも変形しずらいことを表わしている。またフラットジャッキ内 の油圧も袖巻構造物の変形とともに若干の変動はみられるが確実 に上昇していることがわかる。このことは載荷方向の変形量が増 加すればするほど空木内の充媜物はより大きな拘束圧を受けるこ とになり, 充填物自身の強度は拘束圧の関数として, 増加するこ とを意味している。またずり充填実木の場合充填の仕方により異 なるが，比較的空吵の多い場合でも載荷初期から油圧の上昇が得 られ, ずりの再配列により空隙が完全に充填されていく様子がう かがわれる。このことは実験後の観察からも明らかであり,ずり は中心から外側に向うに従い小さく破壊され空隙を密に充媜して いることが認められた。なおこれら充媜実木の木材亀裂状況は空 木の場合とほとんど同様である。

これら 4 つの計測結果を比較してみると, 袖巻構造物として変 形しずらいという観点からは木積, ずり充填実木, スラリー充垻 実木, 空木の順であり, いずれも徐荷後大きな復元力を有し, 弾 力性に富んでいる。このことは衝撃力に対する一種のクッション 材の作用をなすことにもなる。また空木，スラリーおよびずり充 
第1表 実 績

\begin{tabular}{|c|c|c|c|c|c|c|c|c|}
\hline 切 羽 名 & $\begin{array}{l}\text { 中央查 } 0 \text { 片 } \\
\text { (本層) } 5 \text { 号 }\end{array}$ & $\begin{array}{l}\text { 中央暻 } 0 \text { 片 } \\
\text { (本殿) } 4 \text { 号 } \\
\end{array}$ & $\begin{array}{l}\text { 中央西 ? 片 } \\
\text { (下尿) } \\
\text { 上添 } 1 \text { 号 }\end{array}$ & $\begin{array}{l}\text { 知人西 } 1 \text { 片 } \\
\text { (林居) } \\
\text { 下部 } 2 \text { 号 }\end{array}$ & 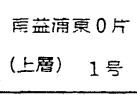 & 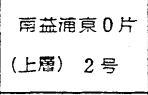 & $\begin{array}{l}\text { 南㫫涌息 } 0 \text { 片 } \\
\text { (上澏) } 3 \text { 号 }\end{array}$ & 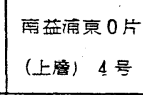 \\
\hline 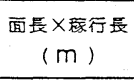 & $\begin{array}{l}150 \times 446.9 \\
115 \times 487.3 \\
\end{array}$ & $141 \times 537.5$ & 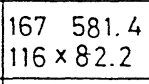 & $127 \times 477.1$ & $130 \times 566$ & $\begin{array}{l}65 \times 115 \\
130 \times 412 \\
\end{array}$ & $\begin{array}{r}130 \times 298 \\
80 \times 167 \\
\end{array}$ & $\begin{array}{l}130 \times 116 \\
181 \times 542 \\
\end{array}$ \\
\hline$山 丈(m)$ & 3.1 & 3.1 & 2.7 & 2.2 & 1.5 & 1.2 & 1.2 & 1.2 \\
\hline 岸 $\quad(m)$ & 2.7 & 2.7 & 1.8 & 1.6 & 1.0 & 1.0 & 1.0 & 1.0 \\
\hline 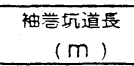 & 934.2 & 475.3 & 581.4 & 409.5 & 566 & 527 & 465 & 320 \\
\hline $\begin{array}{c}\begin{array}{c}\text { 岸 } \\
\text { (1ン) }\end{array} \\
\end{array}$ & 422611 & 282214 & 266703 & 130393 & 99829 & 92224 & 68288 & 147425 \\
\hline 袖堂坑道 & ゲート坑道 & $\begin{array}{l}\text { ゲート坑道 } \\
\text { 風坑として } \\
\text { 2度使用 }\end{array}$ & 風坑 & ゲート玾邉 & 囯 & 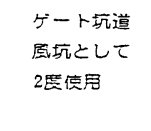 & 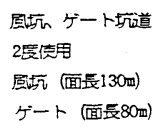 & 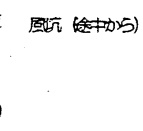 \\
\hline
\end{tabular}

埧実木の挙動を比較すると, その変形量の大きさは充媜物の性質 に依存しており, 空木はその下限に対応している。すなわち充填 物強度が大きくなるに従い空木からずり充填実木の方へ変形挙動 はシフトするものと考えられる。このことは充填物自身の強度を 把握することにより, ある程度袖巻構造物の変形挙動が推定でき ることを示唆している。一方ここで得られた挙動を袖巻坑道へ直 接応用することも可能である。たと学ば坑道の袖巻構造物の変形 量をモニタすることにより，それに作用している荷重の大きさを 類推することができ, さらにこれらと盤膨れ状況調査とを組み合 わせることにより，下艋の急激な隆起すなわち山はね危険性区域 をもある程度評価できるであろう。

このように袖巻構造物の荷重〜变位曲線は実際の袖巻坑道から の情報を得るためのいわゆる検定曲線を表わしており，これらを
もとにより正確な坑道維持管理が可能となる。

\section{4. 実績およびまとめ}

3.で述べたような変形挙動を有する袖巻構造物を用い，現在ま で採炭された切羽の数は重複使用も含め第 1 表に示すように 8 切 羽である。その内訳は中高層が 4 切羽, 薄層が 4 切羽であり, 総 袖巻坑道長は約 $4 \mathrm{~km}$, 総出炭量はほぼ 150 万 $\mathrm{t}$ の実績を有して いる。また袖巻構造物の構築作業は切羽進行速度に十分追従でき, 採炭作業に何ら支障をきたさなかつた。なお重複使用前には下般 打ちならびに枠入替作業の必要はあつたが，本方式は無炭柱採炭 等の理由により, 実収率が向上ししかもコスト的にもかなり有利 な結果が得られた。今後ここでの試験結果を袖巻坑道の維持管理 に応用しつつ本方式を推進していく所存である。

\section{[一般講演}

（7）芦別炭鉱における急傾斜用軽量自走支保とブーム型 採炭機の現場試験（第 2 報）

(財) 石炭技術研究所 坂 田 純一・藤 沢章 三井石炭鉱業 (株) 芦別鉱業所塚 本 慶四郎・木下 和 郎

\section{1. まえがき}

現在の急傾斜層採炭方法は従来より偽傾斜全充てん欠口採炭法 が主流であり，一部水力採炭法が採用されているのが実状である。 一方緩中傾斜層においてはドラムカッタ，ホーベル等の採炭機械 と自走支保を組合せた採炭法が大半で, 切羽からの大量高能率出 炭指向により機械はますます重装備化する方向にある。

しかし，わが国のように断層，しゆう曲が多く片盤長が長く取 れない急傾斜層の自然条件下では切羽大量出炭を目指して, 前記 の重装備をそのまま導入することは傾斜上の制約はもとより設置, 撤収の困難さと採炭コストの高騰を招く結果となる。

したがつて, 急傾斜層に適した機械化採炭を促進すべく, 軽量 で傾斜対策を施した, 設置, 撤収工数の極力少ない片盤向自走支 保と $40^{\circ}$ 前後の傾斜に対応した軽量採炭機の開発を行なつている。 今回は昨年度に報告したものに続く第 2 報ということで, その後 の経過を報告する。

\section{59 年度現場試験}

前回も報告したとおり 59年度の試験では，56～58年度に発破， 炭流しトラフと組み合せて試験を実施した軽量自走支保 1,2 号機
20 枠に鉄柱の降縮荷重を 1.5 倍の $75 \mathrm{t} \times 2$ 本に強化した 3 号機 14 枠を加えた計 34 枠の軽量自走支保と「立傾斜用ブーム型切削機」 を急傾斜用に改造した採炭機, 採炭機を搭載することのできるダ ブルチェーンコンベャを組み合せて現場試験を実施した。今回の 試験より急傾斜層の機械化採炭への第 1 歩を踏み出したわけであ る。その実績を第 1 表に示す。

平均採炭能率は $9.12 \mathrm{t} /$ 人日であり, 58 年度に発破, 炭流しト ラフと組み合せた試験の実績（7.54 t/人日）を上回りはしたもの の急傾斜欠口採炭法での平均採炭能率 $(11 \sim 12 \mathrm{t} /$ 人日 ) には至 らなかつた。また今回の試験では次のことが判明した。

（1）軽量自走支保は, 跡山天盤のばれも良好で $1,2,3$ 号機と もにリリーフ压に達しても降縮量は微量であり, 今回の試験では 十分な強度を有した。

(2) 肩，深ともにステーブルがあり，そのさく孔，発破作業に 時間を要した。

（3）深坑道の枠脚を外していかないため, 採炭機, 切羽コンベ ヤのケーブルの切替作業に時間を要した。

（4）採炭機巻き上げ用のローブ巻装置が矢弦車と一体物のため 移設作業に時間を要した。

（5）下盤切削不良により，コンベヤ前の手積，下盤打ち作業が 